\title{
Reorganising the Working Time System of a Call-Centre with Personnel-oriented Simulation
}

\author{
Patricia Stock and Gert Zülch \\ University of Karlsruhe, ifab-Institute of Human and Industrial Engineering, Kaiserstrasse \\ 12, D-76131 Karlsruhe (Germany). \\ Email: \{patricia.stock, gert.zuelch\}@ifab.uni-karlsruhe.de
}

\begin{abstract}
The configuration of a working time model is a very complex task due to the fact that different restrictions concerning work demands and employee preferences have to be taken into account. The use of a simulation tool is a promising approach as it allows for an objective, quantitative, efficient and prospective assessment of alternative working time models during the design phase. This paper presents a simulation study within a call-centre of manufacturer of electric devices.
\end{abstract}

Key words: Personnel-oriented simulation, Working time configuration, Service sector

\section{REQUIREMENTS OF THE WORKING TIME CONFIGURATION}

In recent years flexible working time systems have been established with the front office of many service departments due to the fact that they enable the adjustment of the assignment of personnel to the fluctuating appearance of customers. The configuration of a flexible working time model has turned out to be a very complex task since, in addition to the interests of the service department and those of the employees, further parameters, e.g. legal regulations or ergonomic recommendations, must be considered (cf. in detail HORNBERGER, KNAUTH 2000, pp. 25). Moreover, the following deficits in working time configuration aggravate the design of an appropriate working time model (cf. BOGUS 2002, pp. 24): 
- Complexity arises from the numerous alternatively or complementary applicable working time models (cf. ACKERMANN 1990, p. 185). Approximately 10,000 different working time models are in use worldwide, clearly illustrating that "the" working time model does not exist (cf. KNAUTH 1995, p. 210). The simple transfer of a general working time model to a specific enterprise case rarely leads to a favourable outcome (cf. KRAMER et al. 1998, p. 17).

- No data regarding the prevalence of or concrete regulations for flexible working time models are available (cf. BUNDESMANN-JANSEN, GROß, MUNZ 2000, p. 23).

- In particular the configuration of flexible working time models with respect to economic and personnel related objectives has been investigated only limitedly. Furthermore, only very few consolidated findings regarding consequences for employee load and strain are available (cf. FERREIRA, LANDAU 2001, p. 245).

- The level of awareness of the involved planers, with respect to configuration possibilities and the consequences of working time models, is very low (cf. FERREIRA, LANDAU 2001, p. 245).

- Conventional analysis methods such as check lists or benefit analyses are only conditionally suitable for the support of the configuration process since an objective, quantitative, efficient and prospective assessment of working time models is only possible to a limited degree (cf. SCHREIER 1995, p. 21).

\section{WORKING TIME CONFIGURATION WITH PERSONAL-ORIENTED SIMULATION}

Therefore, the use of a personnel-oriented simulation tool is a very promising approach since, with its help, the effects of different working time models can be analysed with respect to their implications and advantages prospectively, during the planning phase (BOGUS 2002, pp. 42). Such a simulation procedure was developed at the ifab-Institute of Human and Industrial Engineering of the University of Karlsruhe. In order to implement the simulation-based approach into the configuration of working times in service departments, several modelling concepts had to be designed:

- A modelling concept for service departments was developed, with which various service departments could be characterised and represented in a simulation procedure. Resources (personnel types and work places), customer types and arrival times (with different arrival time distributions) as well as the corresponding activities (with different operation time dis- 
tributions) can be modelled according to the business facility being considered.

- A concept was developed, with which working time models can be modelled. The configuration elements duration, placement and reference time frame of the working times are considered. Furthermore, due to the necessity for precise employee employment for the assessment of working time models using simulation, a heuristic has been developed for the definition of flexible working times. Thus, not only single working time models can be assessed, rather also complex working time systems (meaning the entirety of different working time models used in the business facility).

- An assessment concept was developed, containing not only enterprise organisational and financial goals, rather also specifically, in simulation determinable, employee-oriented goal criteria. The possibility to comparatively assess various working time models with respect to their expected workload and the effects thereof, using the example of time stress and aggregated physical load, was thereby created.

The modelling concepts described above were integrated into the objectoriented simulation procedure OSim (Object Simulator), developed earlier at the ifab-Institute (see ZÜLCH, FISCHER, JONSSON 2000). The simulation procedure OSim-GAM (OSim for Working Time Configuration), which was thereby created, can assess working time models efficiently and in a quantitative manner. A detailed representation of the simulation procedure OSimGAM can be found in BOGUS (2002) or BOGUS and STOCK (2002).

\section{WORKING TIME CONFIGURATION OF A CALL-CENTRE}

In a simulation study the working time system of a call-centre in the semi-industrial service sector was modelled and simulated. In the following the call-centre, the approaches and the results are sketched (see also ZÜLCH, STEIH, STOCK et al. 2004).

\subsection{The Call-Centre}

The manufacturer of electric devices has set up a call-centre to take care of the "after sales service" for his large array of products. The call-centre can be reached through three different telephone numbers, which are structured according to the type of inquiry: 
- the order processing, in which, in addition to the registration of orders, information regarding delivery, prices and discounts, as well as general information is provided and in which complaints are processed,

- the spare parts ascertainment, in which the specification of spare part is carried out, and

- the workshop information desk, in which questions regarding guarantees, goodwill, backorders etc. are answered and information regarding repair releases is given.

The customers can also direct their questions to the call-centre via email or fax. The personnel at the call-centre is comprised of three full-time employees with a working time of 35 hours per week and one part-time employees with a working time of 20 hours per week, for each of the three telephone numbers.

The broad product pallet leads to a differentiated customer structure: It is primarily divided into the sectors "retailers" and "end-consumers". This customer structure results in a fluctuation in the frequency of customer inquiries: The end-consumers prefer to take advantage of the call-centre late in the afternoon, whereas specialised trade customers, who represent the largest group, make demands upon the call-centre mainly in the morning or early afternoon. In addition to the daily fluctuations, the call volume exhibits characteristic variations throughout the course of the week or year.

These conditions place various demands on the working time model to be implemented:

- The large proportion of retail customers forces the call-centre to align its business hours with those of the retailers. These are however longer than the individual working times of the call-centre employees.

- In order to provide a high degree of availability at the call-centre the personnel employment must be aligned with the call volume (Figure 1). This ensures, for one, that the customers can be served promptly, even during peak call times, and that they are not lost (e.g. through breaking due to too long waiting times). On the other hand, a high degree of personnel utilisation should also be achieved. Appropriate key figures, which describe the call volume in detail, are a pre-requisite for a customer-oriented alignment of the personnel requirements, e.g. the rate of the incoming calls and the necessary service times.

- Aside from the operational aspects, the individual working time wishes and the stress of the employees resulting from the work tasks must also be accommodated. 


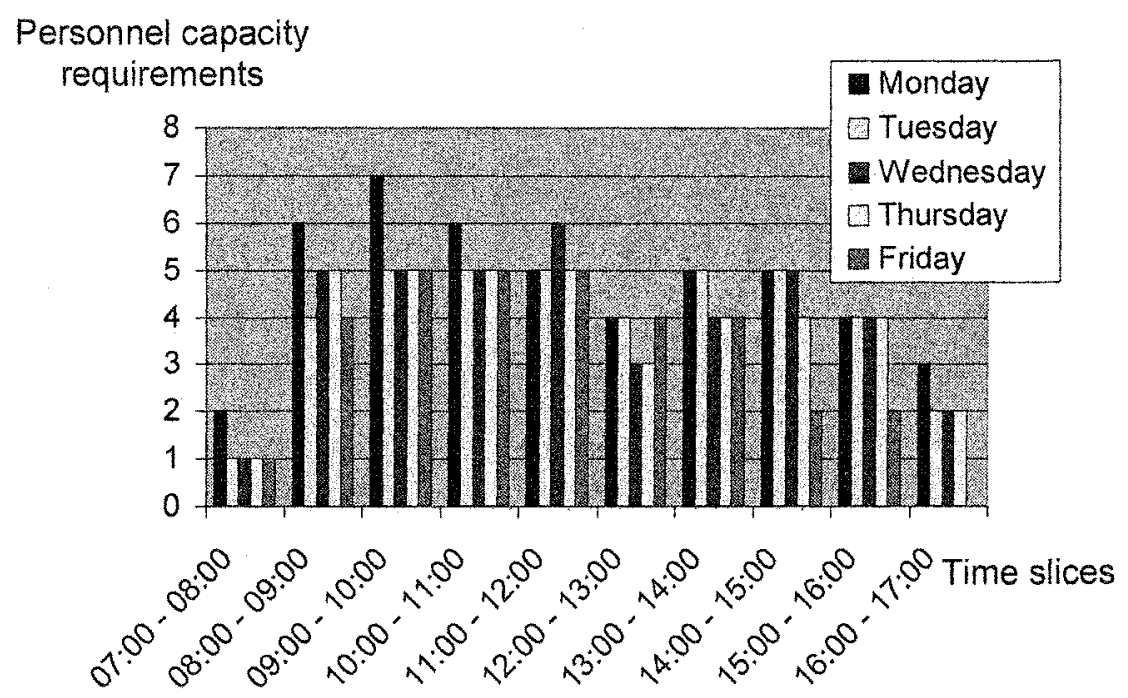

Figure 1 . Personnel capacity requirements according to the call volume

\subsection{Modelling of the Call-Centre}

In the following the initial situation will be described by modelling the customer types, the employees as well as the working time model, in accordance with the modelling concept sketched in section 2 . This step is necessary for validating the simulation model by comparing simulation results with real data.

Considering the types of inquiries arising in the call-centre, the following four customer types can be differentiated:

- calls to the order processing call number $A B$,

- calls to the call number EB for spare parts ascertainment,

- calls to the workshop information desk call number $W A$ as well as

- written fax inquiries or inquiries over the internet $F I$.

The modelling of these various types of inquiries is carried out using activity networks (JONSSON 2000, pp. 55). An activity network shows, in a type of net representation, the temporal logical dependencies of the sequentially succeeding, parallel processing or alternatively occurring activities of inquiry processing. Figure 2 presents an example activity network for the processing of the written fax and internet inquiries. In this example an activity for the distribution of the written inquiries is modelled. This task can be carried out by all of the call-centre employees. One employee from each of the call numbers is responsible for the incoming faxes. In contrast to tele- 
phone customers, the fax enquiries are not associated with a specific waiting time.

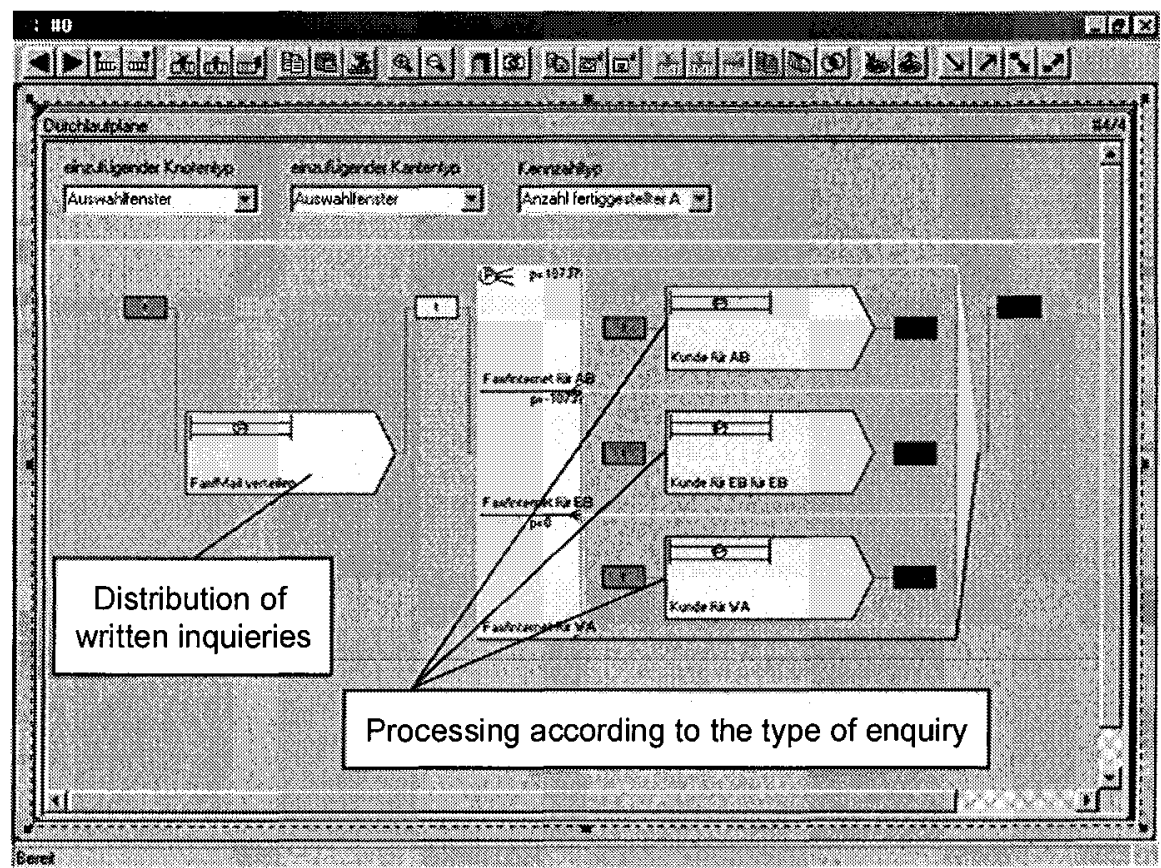

Figure 2. Activity network for customer type "written inquiries"

In the initial situation the call-centre's regularly present personnel is composed of three full-time employees, with a weekly working time of 35 hours, and one part-time employee, with a working time of 20 hours, for each of the groups responsible for customer types $A B, E B$ and $W A$. This results in a personnel inventory of 12 persons with an available personnel capacity of 75 hours per day. Each employee is modelled along with his respective weekly working time, minimum and maximum daily work duration as well as the fixed and variable employment costs.

Subsequently, the persons and activity networks are linked with one another through the definition of individual qualifications. Figure 3 shows the resource links for the activity network "written inquiries" in a so-called functions-equipment-matrix. The columns and rows of the matrix describe all arising functions and available employees respectively. The qualifications of each employee are modelled through a selection of matrix elements, the so called function elements. 


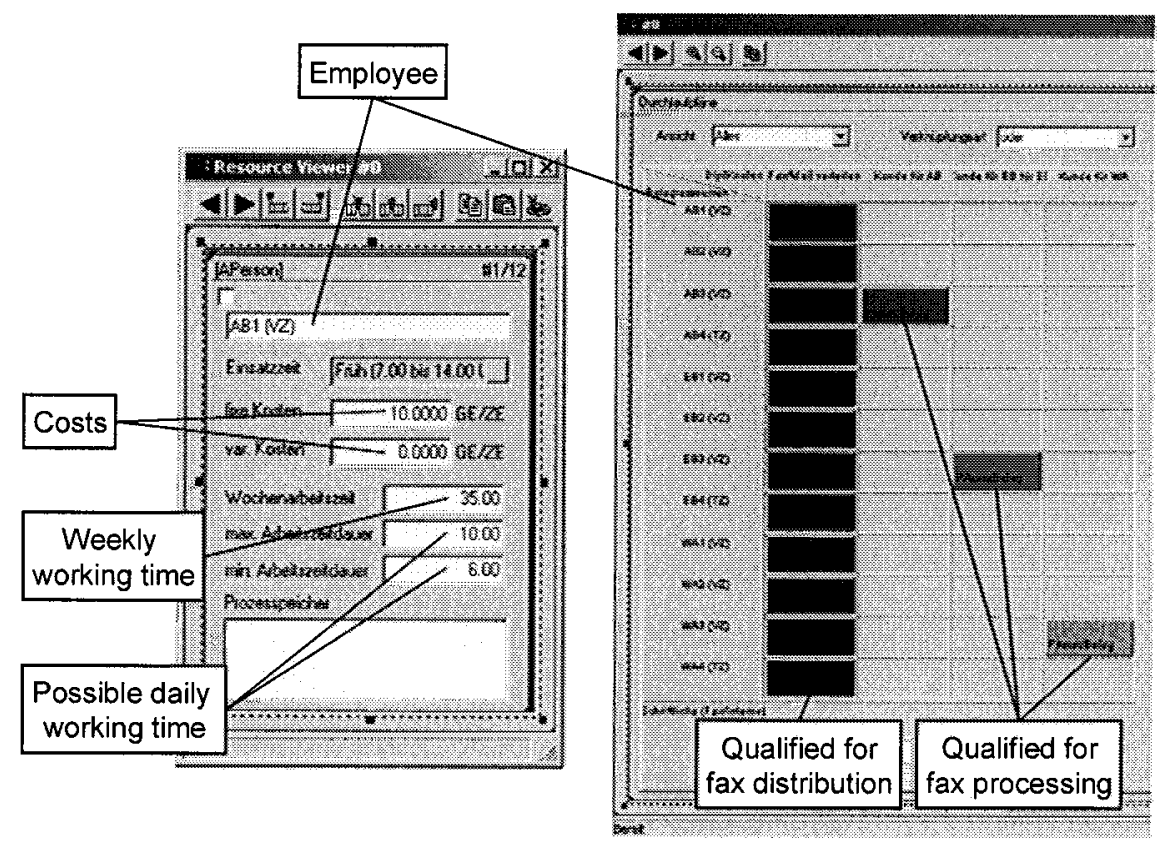

Figure 3. Modelling the employees and their qualifications

In the initial situation various working time models exist, differentiated according to work forms:

- The weekly working time of the full-time personnel comprises 35 hours with a minimum work duration of 6 hours per day and maximum work duration of 10 hours. The full-time personnel work in 4 shifts with a cycle time of 3 weeks.

- The weekly working time of the part-time personnel comprises 20 hours with a minimum work duration of 3 hours per day and a maximum work duration of 10 hours per day. The part-time personnel work form $10 \mathrm{am}$ to 2 pm daily.

Once the working time models of the various work forms have been modelled they are assigned to the individual persons in the employment plan for the entire simulation time period. Figure 4 shows example employment times for the working time model in the initial situation.

The validation of the simulation model results with real data shows that the service degree of the simulation is approximately $10 \%$ lower than the real service degree. This deviance can be traced back to the fact that the existing real data do not possess the needed differentiation, necessary for the simulation, regarding the distribution of incoming inquiries as well as regarding the processing times of the individual functions. This is in turn due 
to the fact that these were, for enterprise regulatory and data security reasons, not registered. Therefore, the required simulation data first had to be calculated using the generalized key figures of the call-centre. Furthermore, no precise data regarding the length of time the customers were willing to wait was available for the simulation study. The waiting time of $20 \mathrm{~s}$ used in the simulation is an optimistic estimate from the call-centre, meaning that, in reality, the customers would probably wait longer. One result that can be deduced is that there are new demands on time management which must be met.

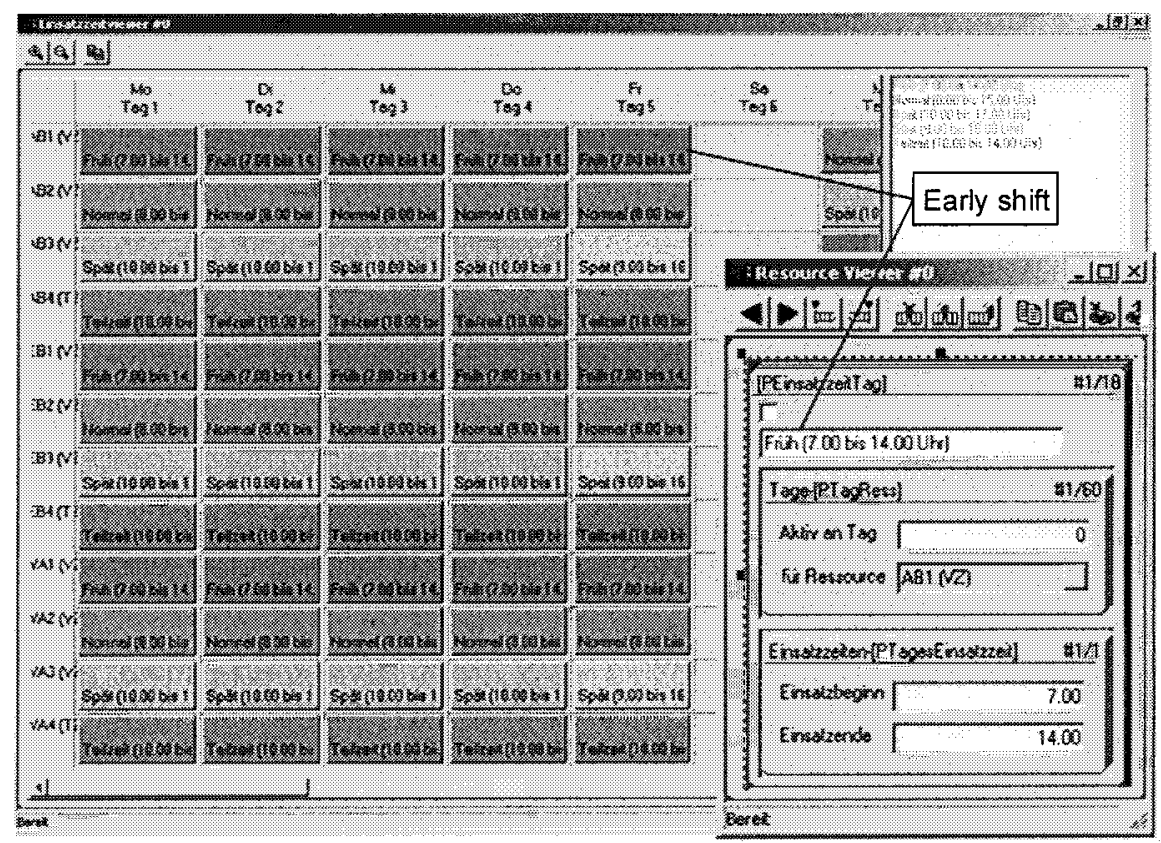

Figure 4. Modelling the working times of the employees

\subsection{Development of the Simulation Alternatives}

Based on the initial situation, various scenarios were developed for the working time systems as alternative configuration solutions. In the simulation study at hand the following alternatives were examined:

\section{- Alternative 1:}

The personnel structure remains constant (meaning the same number of full-time and part-time personnel and in total the same personnel capacity as in the initial situation), and both the full-time and the part-time personnel work in a flexible working time model. 
- Alternative 2:

The personnel structure remains constant and the full-time personnel continue to work in a shift model, while merely the part-time personnel work in a flexible working time model.

- Alternative 3:

The existing personnel structure is changed in that, with a constant personnel capacity, exclusively part-time personnel are employed, with flexible working times.

In order to define the concrete employment times the corresponding heuristic implemented in OSim-GAM is used for the simulation of these alternatives. In general this can lead to relatively complex employment plans, e.g. the employment plan for alternative 1 contains more than 50 different employment times.

\subsection{Results of the Simulation Study}

For the execution of a simulation study it is not sufficient to simulate the modelled working time systems one time only. Rather, it is necessary to repeat the simulation several times in order to eliminate random variations of the results (cf. NEUMANN, MORLOCK 1993, p. 702). Therefore, the initial situation as well as each of the three alternatives were simulated and evaluated with twenty different random number seeds. The degree of goal achievement for "workload", "service degree", "lead time", "physical stress", "time stress", "used capacity costs" und "process costs" are used for the evaluation of the alternatives (in particular in comparison with the initial solution).

In Figure 5 the results of the simulation study are presented as a comparison of the working time system alternatives and initial situation. Very differing consequences, dependent upon the simulated working time system, can thereby be seen. In some assessment criteria an alternative led to a marked improvement, but to an extent, also to a deterioration in others. The results are at least significant on the .01 level, with the exception of the degrees of goal achievement for lead time in alternative 1 and 2 as well as for process costs in alternative 2 .

With respect to the logistical criteria, alternative 1, with its consistent flexible working time regulation, led to an improvement in the degree of goal achievement for workload and service degree, but to a deterioration of the lead time. The monetary assessment criteria attained the highest value here in comparison with all other alternatives. The higher customer service rate can be noticed in an increased degree of physical stress (seen here as a negative change to the corresponding degree of goal achievement). 
In alternative 2 the restriction of the flexible working time to merely the part-time personnel brings with it a great improvement in the degree of physical stress of the workers in general. Since the minor deterioration of the lead time and the customer process costs are barely noticeable this is the alternative for which implementation can be suggested.

In contrast, alternative 3, with its total abandonment of full-time personnel, is not feasible for the service department at hand. Nevertheless, this alternative is worthy to be considered for the reorganisation of a further callcentres. This alternative is marked by the shorted lead times, but also by a slightly lower service degree. This in turn has an impact upon the process costs. Considering the personnel related aspects, the slightly increased workload also led to an increase in the physical stress.

\section{Changes compared to the initial situation}

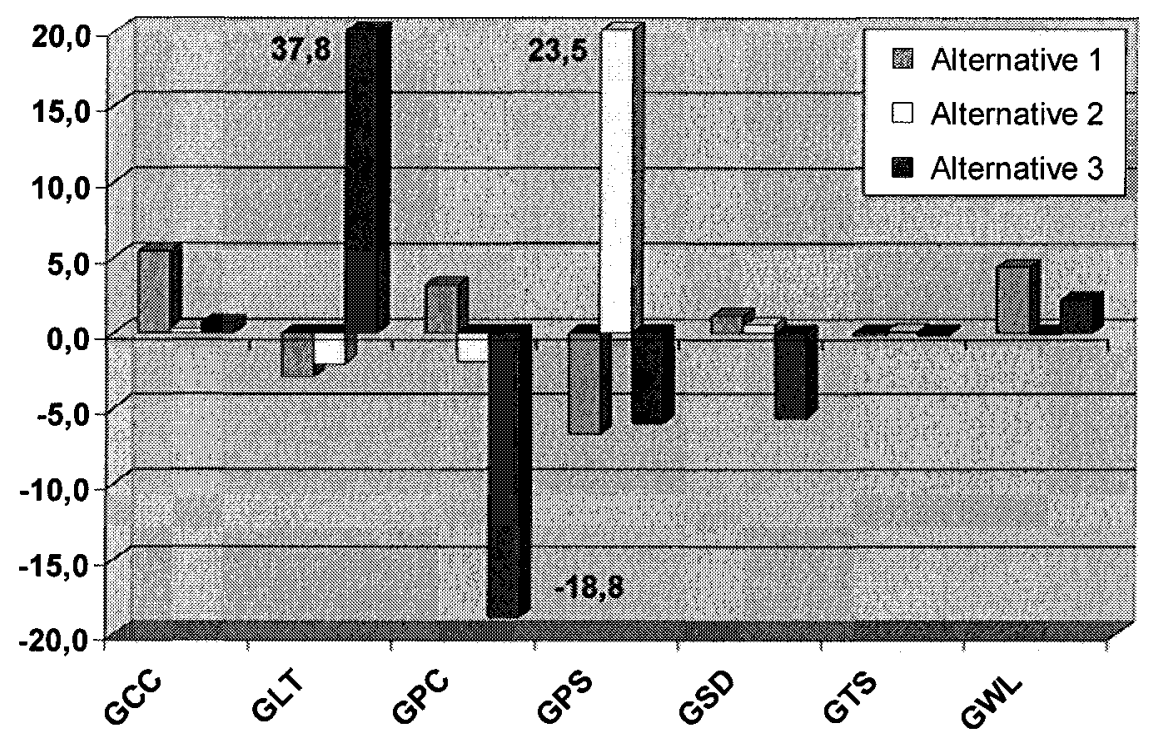

Goal achievement for ...
GCC: Used capacity costs
GLT: Lead Time

GPC: Process costs

GPS: Physical stress

GSD: Service degree
GTS: Time stress

GWL: Work load

Figure 5. Simulation results

(following to ZÜLCH, STEIH, STOCK et al. 2004) 


\section{CONCLUSIONS}

Working time configuration has proven to be a highly complex problem, whose solution is influenced by very differing general conditions. Furthermore, the estimation of the consequences of working time systems is very problematic: Common evaluation methods such as benefit analyses deliver subjective, meaning relatively unreliable, results. Due to the considerable organisational changes, it is generally too laborious to introduce several working time systems into a business in order to prove them. Further difficulties arise from the fact that those responsible for working time configuration possess only limited knowledge regarding existing possibilities.

In particular in service departments, with customer-dependant personnel requirements, business-specific working time models are appropriate in order to provide the customers with the highest level of availability possible. The simulation-based approach has proven to be a suitable means of configuring and assessing working time systems: In the semi-industrial service sector, the expansion of the work content with indirect functions resulted in non-deterministic employment demands, which can only be represented and simulated adequately with probability distributions.

The presented personnel-oriented simulation procedure OSim-GAM contains a modelling concept for the generic representation of differing service departments and work systems. Furthermore, capacity-based employment plans in flexible working time models can be developed using an integrated heuristic. In the scenario simulation of the call-centre of a manufacturer of electric devices, various working time systems were simulated and assessed with this approach. The results extend beyond the recommendation of flexible working time regulation for part-time personnel, to the fact that qualification expansion could also lead to an improvement in the degree of goal attainment for various criteria.

\section{ACKNOWLEDGEMENTS}

This work was funded within the FAZEM-Project "The Effects of Flexible Working Time Models on Personnel Employment and Personnel Strain" by the German Federal Ministry of Education and Research within the framework program "Innovative Arbeitsgestaltung - Zukunft der Arbeit" (Innovative Work Configuration - The Future of Work) (Project No. 01HR9954). A detailed representation of the FAZEM-Project can be found in STOCK and BOGUS (2002), BOGUS and STOCK (2002), ZÜLCH, BOGUS, FISCHER (2002) or ZÜLCH, STOCK and BOGUS (2003). 


\section{REFERENCES}

ACKERMANN, Karl-Friedrich:

Prozeßstandardisierung des Arbeitszeitmanagements. In: Innovatives Arbeits- und

Betriebszeitmanagement.

Eds.: ACKERMANN, Karl-Friedrich; HOFMANN, Mathias.

Frankfurt/M., New York: Campus Verlag, 1990, pp. 183-212.

BOGUS, Thomas:

Simulationsbasierte Gestaltung von Arbeitszeitmodellen in Dienstleistungsbetrieben mit kundenfrequenzabhängigem Arbeitszeitbedarf.

Aachen: Shaker Verlag, 2002.

(ifab-Forschungsberichte aus dem Institut für Arbeitswissenschaft und

Betriebsorganisation der Universität Karlsruhe, Vol. 31)

BOGUS, Thomas; STOCK, Patricia:

Simulationsbasierte Gestaltung von Arbeitszeitmodellen.

In: Arbeitszeitflexibilisierung im Dienstleistungsbereich.

Eds.: ZÜLCH, Gert; STOCK, Patricia; BOGUS, Thomas.

Aachen: Shaker Verlag, 2002, pp. 141-155.

(ifab-Forschungsberichte aus dem Institut für Arbeitswissenschaft und

Betriebsorganisation der Universität Karlsruhe, Vol. 28)

BUNDESMANN-JANSEN, Jörg; GROß, Hermann; MUNZ, Eva:

Arbeitszeit ' 99 . Ergebnisse einer repräsentativen Beschäftigtenbefragung zu traditionellen und neuen Arbeitszeitformen in der Bundesrepublik Deutschland.

Ed.: Ministerium für Arbeit, Soziales und Stadtentwicklung, Kultur und Sport des Landes Nordrhein-Westfalen.

Köln: Institut zur Erforschung sozialer Chancen, 2000.

FERREIRA, Yvonne; LANDAU, Kurt:

Umsetzungen flexibler Arbeitszeitregime am Beispiel eines deutschen Großflughafens.

In: Arbeitsgestaltung, Flexibilisierung, Kompetenzentwicklung.

Ed.: Gesellschaft für Arbeitswissenschaft.

Dortmund: GfA Press, 2001, pp. 245-250.

(Jahresdokumentation 2001)

HORNBERGER, Sonia; KNAUTH, Peter:

Innovative Flexibilisierung der Arbeitszeit.

In: Innovatives Arbeitszeitmanagement.

Eds.: KNAUTH, Peter; ZÜLCH, Gert.

Aachen: Shaker Verlag, 2000, pp. 23-49.

(ifab-Forschungsberichte aus dem Institut für Arbeitswissenschaft und

Betriebsorganisation der Universität Karlsruhe, Vol. 22)

JONSSON, Uwe:

Ein integriertes Objektmodell zu durchlaufplanorientierten Simulation von Produktionssystemen.

Aachen: Shaker Verlag, 2000.

(ifab-Forschungsberichte aus dem Institut für Arbeitswissenschaft und

Betriebsorganisation der Universität Karlsruhe, Vol. 21) 
KNAUTH, Peter:

Was kann das betriebliche Zeitmanagement zur sozialverträglichen Gestaltung von

Arbeitszeiten beitragen?

In: Sozialverträgliche Arbeitszeitgestaltung.

Eds.: BÜSSING, André; SEIFERT, Hartmut.

München: Rainer Hampp Verlag, 1995, pp. 209-220.

KRAMER, Ulrich; BURIAN, Klaus; GERBRACHT, Petra et al.:

Wettbewerbsstärke und bessere Vereinbarkeit von Familie und Beruf - kein Widerspruch. Stuttgart, Berlin, Köln: Verlag W. Kohlhammer, 1998.

(Schriftenreihe des Bundesministeriums für Familie, Senioren, Frauen und Jugend, Band 152)

NEUMANN, Klaus; MORLOCK, Martin:

Operations Research.

München, Wien: Hanser Fachbuchverlag, 1993.

SCHREIER, Jürgen:

Flexible Arbeitszeitregelungen sind kein Privileg von Großunternehmen.

In: Maschinenmarkt,

Würzburg, 101(1995)16, pp. 20-21.

ZÜLCH, Gert; BOGUS, Thomas; FISCHER, Jörg:

Integrated Simulation and Workforce Assignment for the Evaluation of Flexible Working Time Models.

In: System Simulation and Scientific Computing.

Beijing: International Academic Publishers/Beijing World Publishing Corporation, 2002,

Vol. I, pp. 353-357.

ZÜLCH, Gert; FISCHER, Jörg; JONSSON, Uwe:

An integrated object model for activity network based simulation.

In: WSC'00 Proceedings of the 2000 Winter Simulation Conference.

Eds.: JOINES, Jeffrey A.; BARTON, Russel R.; KANG, Keebom et al.

Compact disk: WSC'00, 2000, pp. 371-380.

ZÜLCH, Gert; STEIH, Marco; STOCK, Patricia et al.:

Simulationsbasierte Gestaltung von Arbeitszeitmodellen im industrienahen

Dienstleistungsbereich. In: Betriebliche Tertiarisierung - Der ganzheitliche Wandel vom Produktionsbetrieb zum "dienstleistenden" Problemlöser.

Ed.: LUCZAK, Holger.

Wiesbaden: Deutschen Universitäts-Verlag, 2004 (in print).

(Schriftenreihe der Hochschulgruppe für Arbeits- und Betriebsorganisation, HAB-

Forschungsbericht 15)

ZÜLCH, Gert; STOCK, Patricia; BOGUS, Thomas:

Working time recommendations for the load reduction of employees in retail stores. In:

Human Performance and Aging, Proceedings Volume 4. Proceedings of the XVth

Triennial Congress of the International Ergonomics Association and the 7th Joint

Conference of Ergonomics Society of Korea / Japan Ergonomics Society "Ergonomics in the Digital Age".

Ed.: Ergonomics Society of Korea.

Seoul: Ergonomics Society of Korea, 2003, pp. 227-230. 